\title{
PENGARUH DUA MACAM PUPUK DAUN DAN DOSIS PUPUK ORGANIK TERHADAP PERTUMBUHAN VEGETATIF JAMBU BIJI (Psidium guajava L.) KULTIVAR CITAYAM
}

\author{
Dharma Mahardika, Kushendarto \& Yohannes Cahya Ginting \\ Jurusan Agroteknologi, Fakultas Pertanian Universitas Lampung, \\ Jl.Prof. Soemantri Brodjonegoro, No.1, Bandar Lampung 35145 \\ E-mail: dharmadika@yahoo.com
}

\begin{abstract}
ABSTRAK
Jambu biji (Psidium guajava $L$ ) adalah satu jenis buah tropis kaya akan kandungan mineral dan vitamin. Buah jambu biji juga dapat membantu meningkatkan kadar trombosit dalam tubuh penderita penyakit demam berdarah dengue (DBD). Hal ini karena jambu biji mengandung beberapa asam amino. Penelitian dilaksanakan di desa Way Huwi Jati Agung Lampung Selatan pada bulan Mei - Agustus 2013. Rancangan perlakuan yang digunakan rancangan faktorial 4x2 (dosis bahan organik dan jenis pupuk daun) dan setiap perlakuan diterapkan dalam rancangan acak kelompok ( RAK ). Faktor pertama Bahan organik (D) empat taraf yaitu 0 (D0), 5 (D1), 10 (D2), dan 15 (D3) kg/ tanaman.Faktor kedua adalah 2 jenis pupuk daun ( H), yaitu pupuk daun Growmore (H1) dan Plant Catalyst (H2) dengan konsentrasi 2 g/l. Plot percobaan dikelompokan berdasarkan diameter batang dan kemiringan lereng. Setiap kombinasi perlakuan diulang tiga kali. Setelah data terkumpul, (homogenitas) ragam diuji dengan uji Bartlett dan (aditivitas) dengan uji Tukey. Setelah data dianalisis ragam, kemudian dilanjutkan dengan uji ortogonal polinomial pada taraf $5 \%$. Hasil penelitian menunjukkan: pengaruh pemberian pupuk daun Plant catalyst memberikan rata - rata panjang tunas $18,68 \mathrm{~cm}$, rata - rata jumlah daun sebanyak 4,2 helai, dan umur daun selama 54,3 hari sedangkan untuk pupuk daun Growmore rata - rata panjang tunas $15,13 \mathrm{~cm}$, jumlah daun 4,09 helai dan umur daun selama 47,4 hari, pemberian dosis pupuk organik 8 - $9 \mathrm{~kg} / \mathrm{tanaman}$ memberikan respons terbaik dalam pertumbuhan pada variabel jumlah tunas, panjang tunas, jumlah daun; pengaruh pemberian dosis bahan organik dengan pupuk daun Growmore dan Plant catalyst terlihat pada variabel waktu muncul tunas dan umur daun, pada perlakuan tanpa bahan organik dengan pupuk daun Growmore menghasilkan waktu muncul tunas lebih cepat dengan rata rata 4,23 hari sedangkan Plant catalyst 4,33 hari. Pada variabel umur daun pada dosis $8 \mathrm{~kg} / \mathrm{tanaman}$ dengan perlakuan pupuk daun Plant catalyst menghasilkan umur daun lebih lama dibandingkan Growmore yaitu, 71,75 hari dan 64,99 hari.
\end{abstract}

Kata kunci: Bahan organik, jambu biji Citayam, pertumbuhan vegetatif, pupuk daun

\section{PENDAHULUAN}

Dewasa ini buah jambu biji merah (daging) yang ada di pasaran masih sedikit dengan tingkat kualitas yang masih tidak memadai. Luas tanaman jambu biji merah di Indonesia hanya sekitar $10.500 \mathrm{ha}^{-1}$ dengan produksi 211.836 ton $^{-1}$ (BPS, 2011). Sejalan dengan meningkatnya kesadaran masyarakat akan pentingnya mengkonsumsi buah segar untuk kesehatan dan perekonomian masyarakat maka permintaan pasar terhadap buah segar akan terus meningkat. Peningkatan permintaan tersebut diperkirakan sekitar $9 \%$ per tahun (Pusat Kajian Buah Tropika, 2009).

Menurut Parimin (2007), pektin (serat larut dalam air) pada jambu biji bermanfaat dalam menurunkan kolesterol, selain itu kandungan tanin dalam jambu biji bermanfaat dalam memperlancar sistem percernaan dan sirkulasi darah serta menyerang virus. Kalium dalam jambu biji berfungsi meningkatkan keteraturan denyut jantung, mengaktifkan kontraksi otot, mengatur pengiriman zat-zat gizi ke sel tubuh, serta menurunkan kadar kolesterol total dan tekanan darah tinggi (hipertensi).

Salah satu jenis jambu biji yang populer saat ini adalah kultivar Citayam. Berdasarkan potensi hasil produksi selama peneliti melakukan kegiatan Praktik Umum di Kabupaten Cianjur, Jawa Barat pada bulan Januari 2012, untuk panen jambu dengan umur tanaman jambu 18 bulan dalam satu tahun dengan jarak tanaman 4x6 serta luas 32 ha dapat menghasilkan produksi hingga 15 ton ha-1 (Reza Utama Saputra, 2012).

Tujuan dalam penelitian ini adalah ( 1 ) mengetahui perbedaan aplikasi dua macam pupuk daun yang memiliki kandungan NPK tinggi unsur mikro rendah dengan kandungan NPK rendah unsur mikro tinggi yang berpengaruh terhadap pertumbuhan vegetatif bibit jambu biji merah kultivar citayam ( 2 ) Mengetahui dosis aplikasi bahan organik terbaik sampai dengan $15 \mathrm{~kg}$ per tanaman yang berpengaruh terhadap pertumbuhan vegetatif bibit jambu biji merah ( 3 )mengetahui interaksi 
dua macam pupuk daun dengan dosis bahan organik yang berpengaruh terhadap pertumbuhan vegetatif bibit jambu biji merah.

\section{BAHAN DAN METODE}

Tempat Penelitian. Penelitian dilaksanakan di kelurahan Way Huwi Jati Agung Lampung Selatan pada bulan Mei sampai bulan Agustus 2013.

Bahan. Bahan - bahan yang digunakan adalah bibit jambu biji kultivar Citayam sebanyak 24 bibit yang berumur 3 bulan dengan masing - masing memiliki 2- 4 jumlah percabangan dengan tinggi tanaman dari pangkal okulasi yaitu $50-75 \mathrm{~cm}$ yang berasal dari balai pembibitan Pekalongan, Kota Metro, Provinsi Lampung, pupuk kandang kambing, pupuk daun Growmore, dan Plant Catalyst. Alat yang digunakan adalah cangkul, "handsprayer", tali plastik, gunting, alat tulis, kertas label, timbangan, penggaris, jangka sorong, selang air dan gayung.

Metode . Rancangan perlakuan yang digunakan adalah rancangan perlakuan faktorial $4 \times 2$ (dosis pupuk NPK dan jenis pupuk daun) dan setiap perlakuan diterapkan dalam rancangan acak kelompok (RAK). Faktor pertama dosis Bahan organik ( D ) yang terdiri dari empat taraf yaitu 0 (D0), 5 (D1), 10 (D2), dan 15 (D3) g per tanaman. Faktor kedua adalah jenis pupuk daun yang terdiri atas 2 jenis pupuk daun ( $\mathrm{H}$ ), yaitu pupuk daun dengan kandungan hara makro tinggi yaitu Growmore (H1) dan pupuk daun dengan kandungan hara mikro yang lengkap yaitu Plant Catalyst (H2) dengan konsentrasi $2 \mathrm{~g} \mathrm{l}^{-1}$. Perlakuan diterapkan pada satuan percobaan dalam rancangan kelompok teracak sempurna, dengan diameter batang dan kemiringan lereng sebagai dasar pengelompokan. Setiap kombinasi perlakuan diulang tiga kali.

Setelah data terkumpul, kesamaan (homogenitas) ragam antar perlakuan diuji dengan uji Bartlett dan kemenambahan model (aditivitas) diuji dengan uji Tukey. Jika asumsi terpenuhi, maka data dianalisis ragam, kemudian dilanjutkan dengan uji ortogonal polinomial pada taraf á $5 \%$.

Pelaksanaan. Penanaman dilakukan pada lubang tanam berdiameter $40 \mathrm{~cm}$ dengan kedalaman $40 \mathrm{~cm}$, penanaman tanaman disusun sesuai pengacakan pada tiap- tiap kelompok. Pengelompokan tanaman berdasarkan kemiringan lereng dan diameter batang. Jarak antar tanaman $2 \times 3$ meter dan jarak antara kelompok 3 meter. Perlakuan bahan organik sesuai dengan dosis perlakuan, aplikasi bahan organik dilakukan setelah pemangkasan yaitu 2 minggu setelah tanam. Pada aplikasi pupuk daun pertama kali dilakukan bersamaan dengan aplikasi bahan organik yang pertama. Waktu aplikasi pagi hari yaitu pukul 08.00 - 09.00. Variabel yang diamati yaitu jumlah daun, pertambahan diameter batang, waktu pemunculan tunas, jumlah tunas yang mucul pada batang utama, panjang tunas dan umur daun.

\section{HASIL DAN PEMBAHASAN}

Berdasarkan hasil penelitian menunjukan bahwa pemberian bahan organik tidak dipengaruhi oleh pemberian pupuk daun pada variabel pengamatan panjang tunas, jumlah tunas, diameter batang, jumlah daun, dan umur daun.

Pada variabel panjang tunas dan jumlah tunas dengan perlakuan Plant catalyst menghasilkan panjang tunas lebih panjang 6,35\% dibandingkan Growmore, dengan nilai rata - rata panjang tunas pada Growmore $15,13 \mathrm{~cm}$ dan Plant catalyst $18,68 \mathrm{~cm}$. Jumlah tunas pada Plant catalyst lebih banyak 7,71\% dibandingkan Growmore dengan nilai rata - rata jumlah tunas pada Growmore 8,75 tunas dan Plant catalyst 9,425 tunas (Tabel 1, Gambar 1).

Pada variabel panjang tunas dan jumlah tunas dapat memberikan pengaruh yang berbeda nyata hal ini dapat disebabkan fungsi dari pupuk daun Plant catalyst dan Growmore yang memiliki kandungan unur hara yang relatif sama, akan tetapi pupuk Plant catalyst lebih bersifat alkalis ( Tim Plant Catalyst, 2002 ). Kemungkinan sifat alkalis tersebut yang membuat unsur hara lebih mudah terserap dan meningkatkan kapasitas tukar kation, sehingga pertumbuhan tunas menjadi lebih baik.

Pada variabel panjang tunas, jumlah tunas, dan jumlah daun dengan dosis $8-9 \mathrm{~kg}$ per tanaman adalah dosis bahan organik yang ideal bagi pertumbuhan tanaman, sehingga perkembangan perakaran tanaman menjadi lebih baik yang pada akhirnya akan merangsang pertumbuhan panjang tunas, jumlah tunas, dan jumlah daun akan tetapi, dengan semakin ditingkatkan dosis bahan organik justru pertumbuhan tanaman tidak memberikan respons pertumbuhan yang baik.

Hal ini dapat terjadi akibat dosis pupuk organik yang mempengaruhi sifat fisik tanah, yakni kemampuan menahan air dan terbentuknya pori - pori tanah. Menurut Indrakusumah (2000) untuk pertumbuhan yang baik bagi tanaman diperlukan suatu keadaan tata air dan udara yang baik dan seimbang sehingga akar tanaman dengan mudah dapat menyerap unsur hara. Dosis pupuk 
Tabel 1. Hasil uji polinomial ortogonal pengaruh dosis bahan organik dan dua jenis pupuk daun terhadap waktu (hari) pemunculan tunas tanaman

\begin{tabular}{|c|c|c|c|c|}
\hline \multirow{2}{*}{ Perbandingan } & \multicolumn{2}{|l|}{ Selisih } & \multirow{2}{*}{ Nilai F Hitung } & \multirow{2}{*}{ signifikansi } \\
\hline & hari & $\%$ & & \\
\hline Pupuk Daun (PD) & & & & \\
\hline $\begin{array}{l}\text { P1 : Growmore vs Plant catalyst } \\
\text { Bahan Organik ( BO ) }\end{array}$ & $4,23-4,33=0,01$ & 2,36 & 0,64 & $\operatorname{tn}$ \\
\hline $\mathrm{P} 2:$ BO-Linier & & & 36,73 & $*$ \\
\hline $\begin{array}{l}\text { P3 : BO-Kuadratik } \\
\text { Interaksi PDxBO }\end{array}$ & & & 57,32 & $*$ \\
\hline $\mathrm{P} 4: \mathrm{P} 1 \mathrm{xP} 2$ & & & 8,1 & $*$ \\
\hline $\mathrm{P} 5: \mathrm{P} 1 \mathrm{xP3}$ & & & 1,43 & $\operatorname{tn}$ \\
\hline
\end{tabular}

Keterangan : * : Nyata pada taraf $5 \%$, tn : Tidak berbeda nyata.

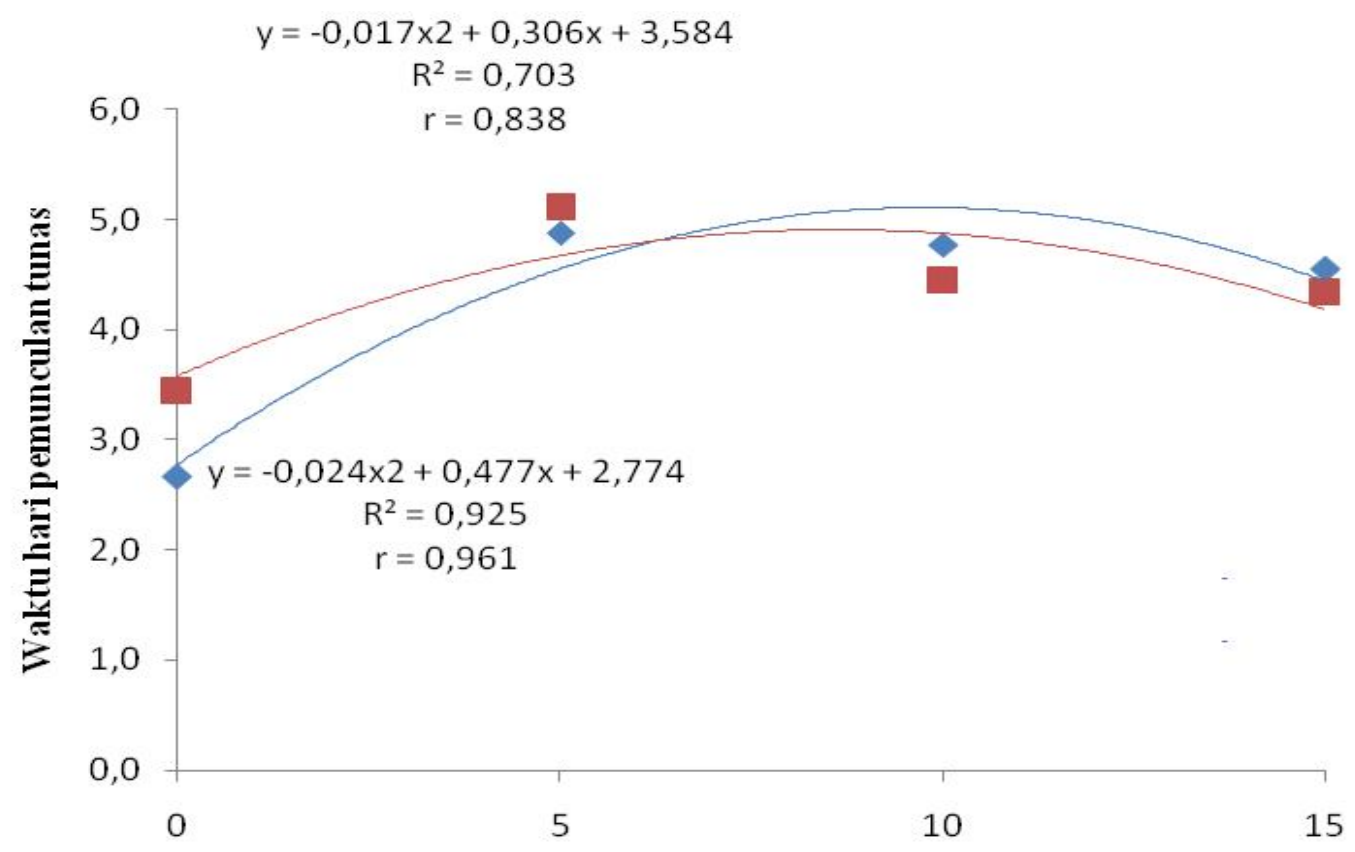

Dosis bahan organik (kg/tanaman)

Gambar 1. Hubungan antara dosis bahan organik dan dua jenis pupuk daun dengan waktu (hari) pemunculan tunas tanaman. * H1 Growmore, _ H2 Plant catalyst, _ Poly. (H1 Growmore), _ Poly. (H2 Plant catalyst).

organik yang lebih dari $9 \mathrm{~kg}$ per tanaman besar kemungkinan menyebabkan daya serap air menjadi lebih banyak, terlebih lagi kondisi lahan penelitian yang rendah serta intensitas hujan yang tinggi maka, pori - pori tanah akan tertutup oleh air. Hal tersebut yang menyebabkan dosis yang lebih tinggi dari $9 \mathrm{~kg} /$ tanaman menyebabkan panjang tunas, jumlah tunas, dan jumlah daun semakin menurun.

Pada variabel waktu muncul tunas, pada dosis bahan organik $0 \mathrm{~kg}$ per tanaman pemberian pupuk daun
Growmore memberikan waktu muncul tunas lebih cepat dibandingkan Plant catalyst sebesar 7,40 \%, sedangkan pada dosis bahan organik lainnya tidak berbeda. Hal ini dapat terjadi karena kandungan unsur $\mathrm{N}$ dan $\mathrm{K}$ pada Growmore lebih tinggi dibandingkan Plant catalyst yakni Growmore N : $32 \%$ dan K : $10 \%$ sedangkan pada Plant catalyst $\mathrm{N}: 0,23 \%$ dan $\mathrm{K}: 0,88$. Menurut Lingga dan Marsono ( 1996 ) peranan nitrogen untuk merangsang pertumbuhan secara keseluruhan, batang, cabang dan 
tunas, sedangkan fungsi $\mathrm{K}$ berperan dalam memperkuat bagian vegetatif tanaman (akar, batang, dan daun ).

Pada variabel jumlah daun dan umur daun, pada perlakuan Plant catalyst menghasilkan jumlah daun lebih banyak 1,08 \% dibandingkan Growmore dengan nilai rata - rata jumlah daun dengan Plant catalyst 4,03 tunas dan Growmore 3,90 tunas. Pada variabel umur daun dengan dosis optimum $8,05 \mathrm{~kg}$ per tanaman dengan perlakuan Plant catalyst menghasilkan umur daun lebih lama 71,75 hari dibandingkan Growmore dengan dosis optimum 8,03 kg per tanaman menghasilkan umur daun 64,99 hari (Tabel 2, Gambar 2). Penggunaan pupuk daun Plant catalyst memberikan pengaruh yang lebih baik dibandingkan Growmore terhadap variabel variabel diatas.

Tabel 2. Hasil uji polinomial ortogonal pengaruh dosis bahan organik dan dua jenis pupuk daun terhadap pertambahan jumlah daun tanaman

\begin{tabular}{|c|c|c|c|c|}
\hline \multirow{2}{*}{ Perbandingan } & \multicolumn{2}{|l|}{ Selisih } & \multirow{2}{*}{ Nilai F Hitung } & \multirow{2}{*}{ signifikansi } \\
\hline & hari & $\%$ & & \\
\hline \multicolumn{5}{|l|}{ Pupuk Daun ( PD ) } \\
\hline P1: Growmore vs Plant catalyst & $3,90-4,03=-0,13$ & 1,08 & 4,63 & $*$ \\
\hline \multicolumn{5}{|l|}{ Bahan Organik ( BO ) } \\
\hline P2 : BO-Linier & & & 0,67 & tn \\
\hline P3 : BO-Kuadratik & & & 11,88 & $*$ \\
\hline \multicolumn{5}{|l|}{ Int eraksi PDxBO } \\
\hline P4 : P1xP2 & & & 0,41 & tn \\
\hline P5 : P1xP3 & & & 0,17 & $\operatorname{tn}$ \\
\hline
\end{tabular}

Keterangan :* : Nyata pada taraf $5 \%$, tn : Tidak berbeda nyata.

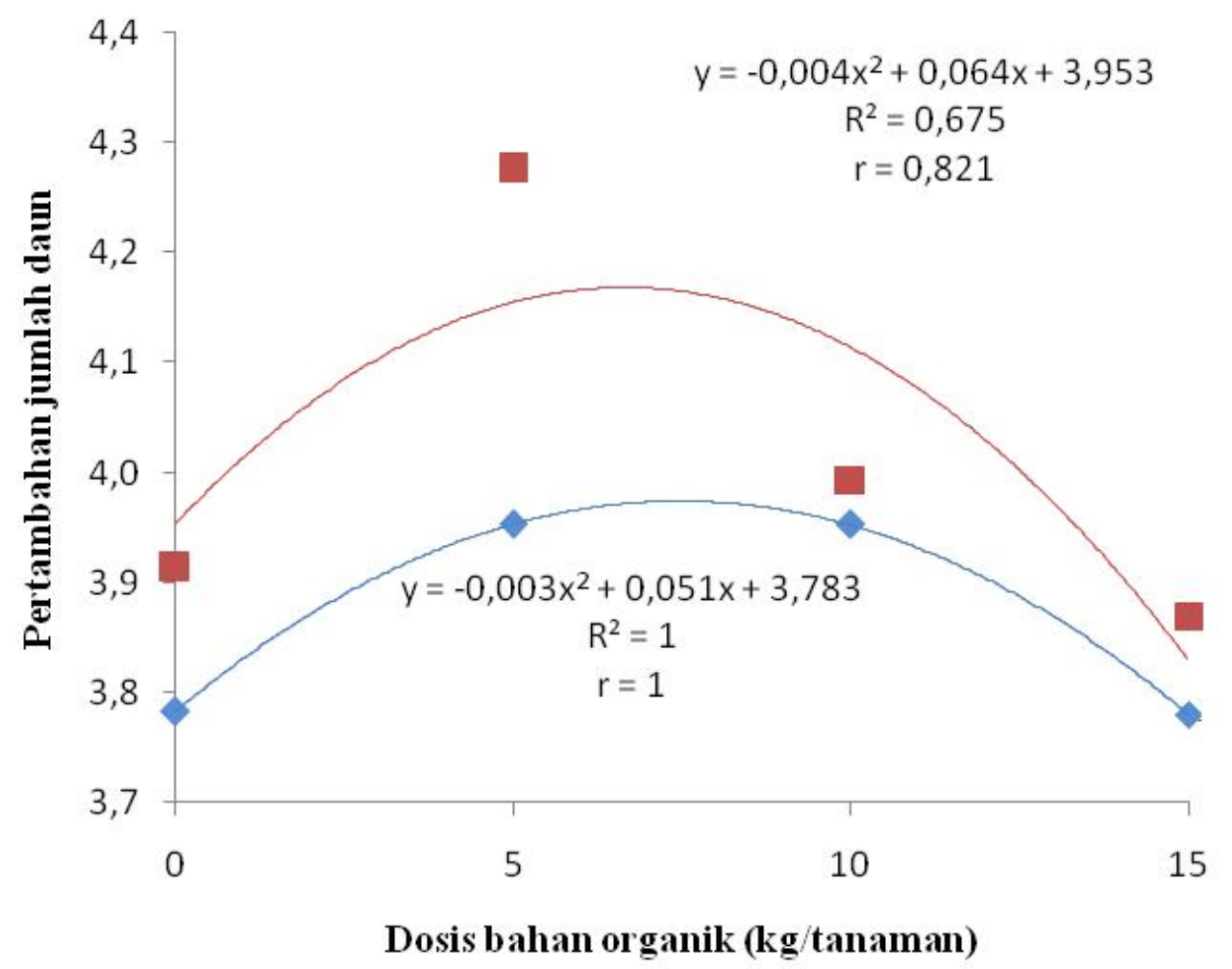

Gambar 2. Hubungan antara dosis bahan organik dan pupuk daun dengan pertambahan jumlah daun tanaman. - H1 Growmore, a H2 Plant catalyst, _ Poly. (H1 Growmore), _ Poly. (H2 Plant catalyst). 
Pada variabel pengamatan pertambahan diameter batang tidak berpengaruh nyata, pada dosis bahan organik pupuk kandang kambing dengan dua jenis pupuk daun, untuk penggunaan pupuk daun Growmore memiliki nilai rata rata pertambahan diameter batang sebesar 4,4 cm sedangkan Plant catalyst 4,38 cm (Tabel 3, Gambar 3). Hal ini dapat disebabkan waktu penelitian yang singkat sehingga hasil pertumbuhan tanaman yang di dapat belum terlihat.

Tabel 3. Hasil uji polinomial ortogonal pengaruh dosis bahan organik dan dua jenis pupuk daun terhadap umur daun tanaman

\begin{tabular}{|c|c|c|c|c|}
\hline \multirow{2}{*}{ Perbandingan } & \multicolumn{2}{|l|}{ Selisih } & \multirow{2}{*}{ Nil ai F Hitung } & \multirow{2}{*}{ signi fikansi } \\
\hline & hari & $\%$ & & \\
\hline Pupuk Daun ( PD) & & & & \\
\hline $\begin{array}{l}\text { P1 : Growmore vs Plant catalyst } \\
\text { Bahan Organik ( BO ) }\end{array}$ & $142,09-162,08=-6,625$ & 4,09 & 9,16 & $*$ \\
\hline P2 : BO-Linier & & & 9,63 & $*$ \\
\hline $\begin{array}{l}\text { P3 : BO-Kuadratik } \\
\text { Interaksi PDxBO }\end{array}$ & & & 156,02 & $*$ \\
\hline $\mathrm{P} 4: \mathrm{P} 1 \times \mathrm{P} 2$ & & & 0,01 & tn \\
\hline P5 : P1xP3 & & & 0,06 & $\operatorname{tn}$ \\
\hline
\end{tabular}

Keterangan : * : Nyata pada taraf $5 \%$, tn : Tidak berbeda nyata.

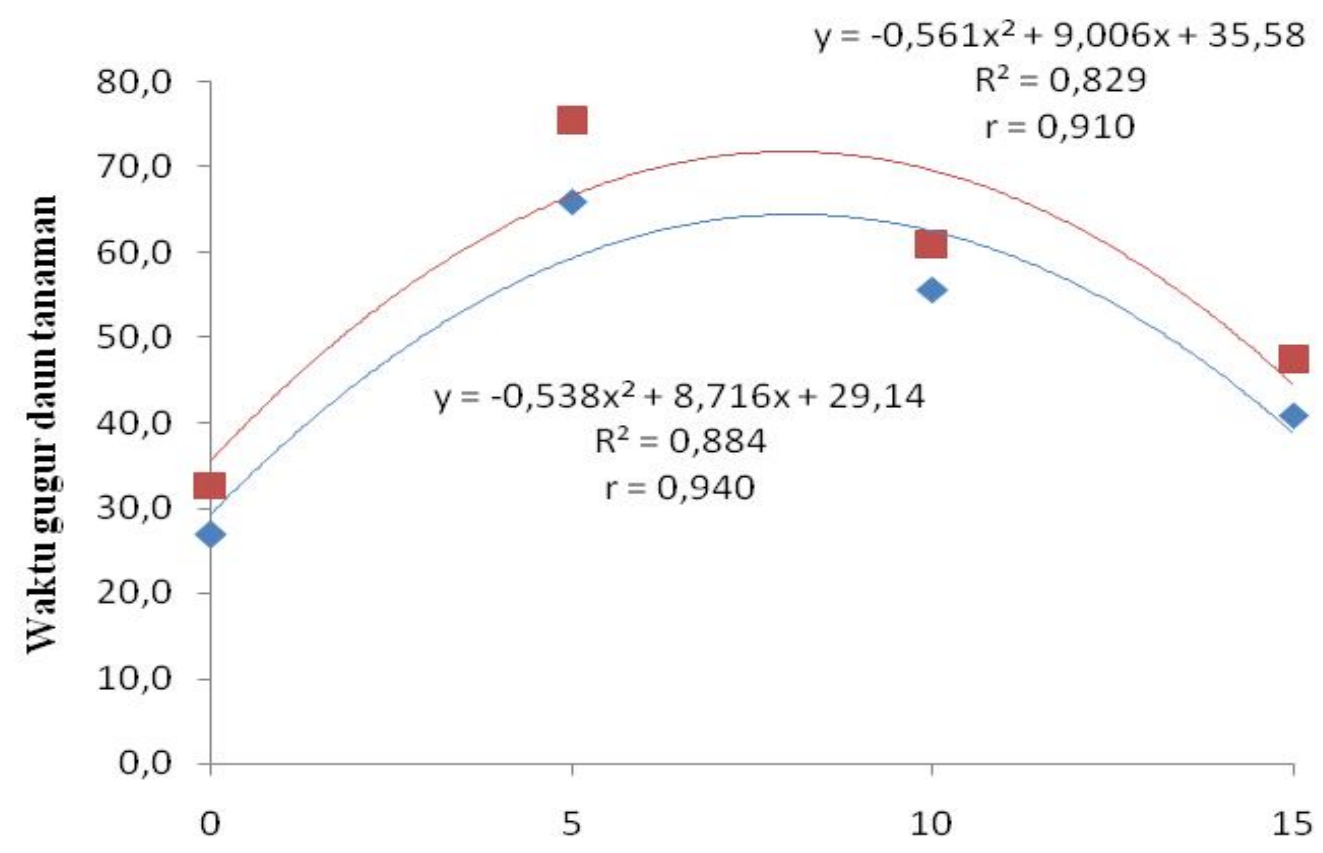

Dosis Bahan Organik (kg/tanaman)

Gambar 3. Hubungan antara dosis bahan organik dan dua jenis pupuk daun dengan umur daun tanaman. $\bullet$ H1 Growmore, $\mathrm{H} 2$ Plant catalyst, _ Poly. (H1 Growmore), _ Poly. (H2 Plant catalyst). 


\section{KESIMPULAN}

Adapun kesimpulan dari hasil penelitian yang telah dilakukan adalah: pengaruh pemberian pupuk daun Plant catalyst memberikan rata - rata panjang tunas $18,68 \mathrm{~cm}$, rata - rata jumlah daun sebanyak 4,2 helai, dan umur daun selama 54,3 hari sedangkan untuk pupuk daun Growmore rata - rata panjang tunas $15,13 \mathrm{~cm}$, jumlah daun 4,09 helai dan umur daun selama 47,4 hari; pemberian dosis pupuk organik $8-9 \mathrm{~kg}$ per tanaman memberikan respons terbaik dalam pertumbuhan pada variabel jumlah tunas, panjang tunas, jumlah daun; pengaruh pemberian dosis bahan organik dengan pupuk daun Growmore dan Plant catalyst terlihat pada variabel waktu muncul tunas dan umur daun, pada perlakuan tanpa bahan organik dengan pupuk daun Growmore menghasilkan waktu muncul tunas lebih cepat dengan rata rata 4,23 hari sedangkan Plant catalyst 4,33 hari. Pada variabel umur daun pada dosis $8 \mathrm{~kg}$ per tanaman dengan perlakuan pupuk daun Plant catalyst menghasilkan umur daun lebih lama dibandingkan Growmore yaitu, 71,75 hari dan 64,99 hari.

\section{SANWACANA}

Ucapan terima kasih disampaikan kepada Ibu Tri Dewi Andalasari, M.S yang telah membantu memberikan ide, bimbingan, motivasi, arahan, dan saran selama penelitian sampai penyelesaian skripsi ini dengan penuh kesabaran.

\section{DAFTAR PUSTAKA}

Badan Pusat Statistik. 2011. Luas Areal dan Produktivitas Tanaman Jambu Biji di Indonesia. http :www.bps.co.id.(Diakses 12 Maret 2013 pukul 20.33)

Indra kusumah. 2000. Peranan Pupuk Organik dan Pupuk Hayati dalam Meningkatkan Produksi Tanaman Hortikultura. Hlm 20. Dalam Prosiding Semnas Peranana Organik dalam Meningkatkan Produksi. Balai Besar Litbang Sumberdaya Lahan Pertanian. Bogor.

Lingga, P dan Marsono. 1996. Petunjuk Penggunaan Pupuk. Penebar Swadaya. Jakarta. $150 \mathrm{Hlm}$ (Diakses 05 Juli 2014 pukul 09.26)

Parimin. 2007. Nilai Gizi Dan Khasiat Jambu Biji. http://eemo - esprit. Blogspot.com.(Diakses 12 Maret 2013 pukul 20.10)

Pusat Kajian Buah Tropika. 2009. Tingkat Konsumsi Buah - buahan di Indonesia. Departemen Pertanian . Pendapatan Nasional. Hortikultura.deptan.go.id. (Diakses 10 Maret 2013 pukl 11.23)

Reza Utama S.2012.Teknik Budidaya Jambu Biji Merah pada PT.SAC Kp.Pasir Munding,Cianjur,Jawa,Barat. Laporan Praktik Umum 2012 Universitas Lampung. 